\title{
La concepción del poema en prosa como obra orgánica en Miguel de Unamuno*
}

\section{Unamuno's Concept of Prose Poem as an Organic Work}

\author{
María Martínez Deyros \\ Instituto Politécnico de Bragança \\ mdeyros@hotmail.com
}

ORCID iD: http://orcid.org/0000-0002-9154-7575

\section{RESUMEN}

A lo largo del presente artículo demostraremos cómo Unamuno, en torno a los años 1912 y 1913, realiza una profunda reflexión poética que le lleva a borrar fronteras genéricas entre la prosa y la poesía. Gracias a los manuscritos de trabajo analizados mediante la metodología de la crítica genética, comprobaremos cómo pone en práctica esta reflexión teórica iniciando la redacción de un poemario en prosa. Asimismo, los apuntes autógrafos del prólogo que planeó para dicho volumen de versos se revelan de suma importancia, pues evidencian que Unamuno concibió el poema como un organismo, para cuya composición intentó desarrollar una secuencia rítmica basada en números impares. Será el endecasílabo el metro al que otorgue un lugar privilegiado dentro de su poética, y llegará a considerarlo como el auténtico «verso orgánico».

Palabras Clave: Miguel de Unamuno; poemas en prosa; borradores de poesía; obra orgánica; endecasílabo; crítica genética.

\begin{abstract}
Throughout this article, we will discuss how Unamuno made a profound poetic reflection; around 1912 and 1913, he eliminated the generic boundaries between prose and poetry. Applying the methodology of genetic criticism to the analysis of the drafts reveals that don Miguel implemented his theoretical reflection by writing a poetic book in prose form. Furthermore, the autograph notes provided in the prologue revealed themselves important. They demonstrated how Unamuno conceived poems as an organism and developed a rhythmic sequence based on odd numbers for his composition. He introduced the hendecasyllable in his poems, which would forever be considered the real "organic verse".
\end{abstract}

* Este trabajo se enmarca dentro de la tesis doctoral Propuesta metodológica para el estudio y la edición de manuscritos hispánicos: la crítica genética y los borradores de poesía de Miguel de Unamuno, cofinanciada por la Universidad de Valladolid y el Banco Santander. 
Key words: Miguel de Unamuno; Prose poems; Poetry drafts; Organic work; Hendecasyllable; Genetic Criticism.

En 1907 publica Unamuno su primer libro de versos, Poesías, con el que pretendía sentar las bases de una nueva concepción poética para la lírica española contemporánea. Sin embargo, la difusión de la obra no tuvo las repercusiones esperadas por parte de su autor. Frente al mutismo y la indiferencia del mundo literario y del público, en general, se alzaron contadas voces en favor del novel poeta. Así, desde las páginas de la revista Ateneo o de El Imparcial, escritores como Mariano Miguel del Val, Francisco Antón Casaseca, Eduardo Gómez Baquero, José Sánchez Rojas o Pedro González-Blanco emprenden una férrea defensa de su poesía, considerada por este último como «necesaria» y «urgente» para la reconstitución nacional (García Blanco 1954: 121-124). Todos coinciden en sus críticas en resaltar la novedad formal que suponen sus versos. En su reseña «Sobre Poesías», el crítico Antón Casaseca expresa su admiración por los poemas unamunianos a través de una hábil metáfora organicista, que le lleva a identificar sus versos, «duros» y «secos», con las raíces, pues ambos arraigan en el interior del corazón, encerrando dentro de sí todo un caudal de vida, "agua de sangre». Son sus poemas raíces fuertes que, rodeadas de soledad y oscuridad, buscan en las entrañas de la tierra el agua pura con la que crear nueva vida. Al igual que el poeta, estas tantean en lo «ignorado» la esencia del misterio, allí donde hallar esa fuente soterraña que alimente la planta. Y esta, en el caso de don Miguel, no podría ser otra que la encina ${ }^{1}$.

No podría resultar más acertada la comparación que el crítico zamorano realiza de la poesía unamuniana, puesto que este árbol centenario y robusto, al igual que los versos del poeta, tarda más que otros en crecer y dar fruto. De esta forma, se justifica que esas «flores de otoño» sean el resultado de una ardua labor poética desarrollada a lo largo de los años. Sin lugar a dudas, las palabras del periodista vienen a coincidir con el pensamiento poético de Unamuno y extraen, con gran habilidad, la esencia de las composiciones de Poesías. Por este motivo, don Miguel decide incluir las ideas aquí apuntadas en el «prólogo-crítico-apologético-poético» (Tellechea 2001: 170) de su próximo poemario, donde se defienda de los ataques recibidos; ataques que, como apuntan diversos críticos, estuvieron motivados, sobre todo, por una fuerte «antipatía personal» (Ribbans 1996: 213).

\footnotetext{
1 «Encinas duras, recias y fibrosas, de eterna hoja, retorcidas y austeras, templadas a fuego y a hielo, firme sostén que no lleva el viento ni el torrente; encinas "todas corazón" serán los árboles que broten de estas raíces. Ya brotarán; acaso no deban brotar todavía. Las encinas tardan mucho en crecer. ¿Comprenderéis ahora por qué no fructifican todavía esas raíces en todos los hombres?» (Antón Casaseca 1907: 485-486).
} 
Ante el fracaso que supone la escasa recepción de su primera obra lírica, don Miguel decide publicar un segundo tomo que le sirva de explicación y defensa de su concepción poética, tan mal recibida en los círculos literarios españoles. A pesar de que algunos estudiosos han identificado este segundo libro de poemas con Rosario de sonetos líricos (Ayuso 2000: 58), nosotros demostraremos cómo se trata de un proyecto que habría que inscribir en un arco de tiempo mucho más amplio, dieciséis años, durante los cuales experimentará diferentes cambios y, en cierta forma, desembocará en las «Visiones rítmicas» de 1922.

Asimismo, habrían conformado esta segunda obra de poesía varias composiciones que, finalmente, vieron la luz en diferentes momentos, ya formando parte de otros proyectos literarios, ya en publicaciones aisladas en revistas o, por el contrario, permanecieron inéditas hasta las antologías de García Blanco en los años cincuenta del siglo pasado.

\section{UN PRÓlOGO Y ALGUNAS POESÍAS (1907-1911)}

Profundamente decepcionado por la pésima acogida de su libro de versos, Unamuno no se arredra y decide dar a la luz una segunda obra de poesía, precedida de un proemio que le sirva para justificar su novedosa concepción poética y refutar las invectivas de sus detractores, quienes le tachan ofensivamente de modernista:

Así que vuelva a Salamanca, dentro de cuatro o cinco días, continuaré en mi Tratado..., en que ya trabajaba. Tengo también un nuevo regular caudal de poesías, que cuando aumente algo publicaré con un prólogo que desarrollaré y defenderé mis puntos de vista (estéticos y técnicos o métricos) al respecto. ¡Se han dicho tales tonterías! Y la mayor la de calificarme de modernista (!!!). Es gabacho todo el que habla una lengua que no entiende, sea francés, rumano, noruego, finlandés o chino. ¡Modernista yo! [Carta dirigida a Antón Casaseca, el 27 de junio de 1907] (Tellechea 2001: 165).

Unos meses más tarde, el 10 de octubre, manifiesta nuevamente la idea de publicar un segundo poemario, a través del que pueda exponer tanto su estética, como su técnica, y nos avanza ya un título, Un prólogo y algunas poesías (Robles 1996: 283). Por otro lado, no será el único proyecto literario que lleve a cabo a lo largo de este año, pues retoma la redacción del Tratado de Amor de Dios y concluye su obra autobiográfica, Recuerdos de niñez y mocedad, cuyas pruebas de imprenta finalizarán en febrero de 1908 (Robles 1991: 239).

A pesar del revés comercial de sus Recuerdos, no decae su inspiración y continúa componiendo versos, como «Aldebarán» o «Llueve», poemas que irá dando a conocer en diferentes revistas. $\mathrm{Su}$ estro poético parece ir en aumento 
acorde con su resentimiento hacia la crítica y público nacional, que continúan sin tenerlo en cuenta como poeta ${ }^{2}$.

En efecto, don Miguel, consciente de la subversión y novedad de sus poemas, siente la presión que desde el centro cultural de la capital se está ejerciendo para silenciar su obra literaria, en especial, la poesía. Por este motivo pone su mira en el extranjero, y no se equivocaba Unamuno al prever que, a través de la prensa internacional y de la traducción de sus obras, se favorecería tanto la difusión de su producción artística, como su figura de poeta universal.

Ante el mutismo de sus contemporáneos, busca el apoyo de literatos jóvenes y extranjeros, como Ernesto A. Guzmán, cuya Vida interna le dará pie para exponer un mismo credo poético, común a ambos autores: «Van tan mezcladas las cosas que de usted y de su poesía diría con las que de mí mismo y de mi poesía habría de decir, que es la cosa delicada en extremo» (Robles 1996: 334).

A lo largo de 1909 informa a sus corresponsales del inicio de la redacción de una novela «por el estilo de Amor y pedagogía» (Robles 1996: 331) y, a finales de año, confiesa su creciente interés por el teatro, género en el que anda «metido de hoz y de coz» (Blázquez 2007: 198), con la representación de los dramas La esfinge, La venda, y la comedia La princesa de Lambra, a las que habría que añadir La difunta, terminada en diciembre de ese año, y Victoria, cuya planificación está comenzando en esos mismos días.

Don Miguel descubre en el teatro un cauce perfecto para plasmar sus innovaciones poéticas, y fruto de esta experimentación nacerá un tipo de drama escrito en «prosa ritmoide, casi verso libre» (Tellechea 2001: 173). Aunque por ahora sigue considerando la rima generatrice como «tirano empurpurado»y «desviadora», por dar «una asociación de ideas externa», en este momento admite su uso, pero de forma independiente al ritmo, «repartida entre los versos, pero no a los finales» (Robles 1996: 347).

En efecto, en la misiva que dirige a su amigo Antón Casaseca, el 18 de abril de 1910, este intento de separar la rima del ritmo, practicado por extenso este año en el teatro, dará también sus resultados en el género lírico y, así, transcribe al periodista la composición que comienza «Cambiemos nuestras cruces», en la que indica expresamente su deseo de «disociar la rima del ritmo.

2 «Y así ocurre que soy, acaso en España, el escritor que a más nombre es menos conocido; mi nombre aparece de continuo en la prensa precedido del "ilustre" u otro epíteto grotesco, pero apenas se analiza y estudia lo que he ido dando. Eso sí, cuando saco ideas del puchero común en que hierve la bazofia cotidiana liberal y las prohijo, dándoles mi nombre - pobrecitas ideas expósitas! - no faltan horates para decir que aquello, que es lo menos mío, es lo mejor mío. Es natural, en el expósito a que di mi nombre reconocen su propio hijo, el hijo de mil padres, el hijo de la gran ramera. Pero mis propios hijos, los de mi alma, van por ahí sin entrar en las casas, pues no los llaman. Pero confío, por de pronto en extranjeros y además en los jóvenes» [Carta a Ricardo Gutiérrez Abascal, del 6 de mayo de 1908] (González de Durana 1986: 193). 
Me dice Pérez de Ayala que ya Garcilaso lo intentó. No lo sé, pues apenas conozco a Garcilaso» (Tellechea 2001: 177).

Por lo tanto, basándose en esta nueva experimentación literaria, preparará un nuevo volumen de versos, de cuya novedad hará partícipe al también poeta Ernesto A. Guzmán, a quien exhortará para unir sus voces en torno a un mismo credo poético ${ }^{3}$.

Sin embargo, a partir de septiembre de 1910, este planificado poemario se verá nuevamente interrumpido, pues, como bien se puede observar por la lectura de sus cartas, su efervescencia lírica derivará en la redacción de un volumen de versos de corte diferente. Se trata de un libro formado íntegramente por sonetos, composición que ha comenzado a cultivar con intensidad durante su estancia vacacional en Bilbao e, incluso, llega a anunciar su recopilación bajo el rótulo Sonetos de septiembre. Este nuevo proyecto aumenta considerablemente al mes siguiente y, en octubre, ya anuncia tener «hechos noventa y cinco» (Robles 1996: 354); pero no piensa detenerse ahí y planea publicarlos en un mismo tomo cuando supere los cien. De esta forma, enfrascado en la conclusión de este volumen de versos, pasará el resto del año hasta bien avanzado el mes de febrero de 1911.

\section{NuEVAS POESÍAS (1911-1914)}

Si a lo largo de 1910 ha ido otorgando diversas concesiones a la rima, en 1911 revelará su completa aceptación a la rima generatrice, al considerarla como un elemento indispensable a la hora de componer poesía, pues es «fuente de asociación de ideas» independiente de la voluntad del poeta. Será en un artículo, publicado en La Nación el día 3 de marzo de 1911, con el título de «El desinterés intelectual», donde dé a conocer las causas de esta evolución poética, motivada por la incesante práctica de componer sonetos.

Sin duda, Unamuno concibe su Rosario de sonetos líricos de forma muy diferente a su anterior poemario. En este caso, el poema no surge por la necesidad de expresar una idea o sentimiento, sino «para desarrollar un endecasílabo, un verso, un frase». Así, la lectura del verso shakespeareano «sweet silent thought», le inspira «el dulce silencioso pensamiento», verso que le sirve de punto de partida para crear una composición. Don Miguel justifica este cambio radical, que a muchos podría resultar contradictorio, diciendo: «Yo, señora, les doy un valor muy relativo a las ideas que expongo, estimando que vale mucho más la manera cómo las expongo, el tono que les doy, el calor que pueda pre-

\footnotetext{
3 «Preparo otro nuevo tomo de poesías, donde intento en parte otra orquestación, disociando la rima del ritmo. Y preparo un folleto de batalla, de crítica, en que habrá frecuentes menciones a las poesías de ustedes, a las de Prado, a las de otros. Hay que agruparse para pelear» (Robles 1996: 350).
} 
sentarlas», y pasa a defender una concepción romántica del nacimiento del poema, identificando la rima con el azar o «primera fuerza creadora» (Unamuno 1966b: 287).

Publicado su libro de sonetos, retoma el propósito de dar a la luz un nuevo tomo de versos, bajo el rótulo de Nuevas Poesías (Robles 1996: 377). Concordamos con García Blanco en que estos «versos» no se pueden referir en ningún caso a los de El Cristo de Velázquez, pues este aparecerá mucho más tarde, en 1920, y tendrá, además, un carácter monográfico, y no antológico. Para el catedrático salmantino, estos poemas, que no llegaron a ver la luz en un mismo volumen, los repartirá su autor, años más tarde, entre las páginas de Andanzas y visiones españolas y Rimas de dentro (García Blanco 1954: 188).

Sin embargo, cuando el hispanista salmantino en su ensayo Don Miguel de Unamuno y sus poesías pasa a estudiar una de las composiciones de ese año, afirma que esta fue relegada al olvido por su autor por tratarse de «un mero pasatiempo» (ibid.: 188). Con este comentario, el hispanista se refiere a un poema inspirado en la lectura de La pata de la raposa, de Ramón Pérez de Ayala; obra que Unamuno se encargó de reseñar en las páginas de La Nación el 13 de agosto de 1912:

... voy a daros aquí una composición que se me ocurrió después de haber leído La pata de la raposa. La composición es en verso y rimada, pero por razones que expondré en el prólogo de mi próximo y tercer volumen de poesías, he venido a resolverme a publicar los versos en la forma tipográfica de la prosa. Así se salvan no pocos inconvenientes y se impide el que cualquier lector le aplique el sonsonete de acordeón o de organillo, ese sonsonete de tamtam congolés que hasta como música —o más bien precisamente como música— es insoportable.

Y, a continuación, reproduce el poema que comienza «¡Ay zorro, zorro, pobre zorro», a reglón seguido. Contrariamente a la opinión de García Blanco, que consideraba esta composición como un mero "pasatiempo», para su autor se trató de un proyecto literario más amplio, madurado con toda seriedad. Estas palabras de don Miguel habría que ponerlas en relación con aquellas plasmadas en el artículo de La Nación mencionado anteriormente, donde justifica su reciente interés por la rima como generadora del concepto y llega incluso a jurar «por los sagrados manes del divino Leonardo, que muchas veces no estoy sino escribiendo sonetos, aunque ni estén rimados ni consten de catorce versos, sino en vulgar prosa. Mucho de esto no es sino poesía pura, sea buena o sea mala».

Es decir, que a través de la constante práctica versificatoria que le ha llevado a componer dramas «en prosa ritmoide, casi verso libre» y sonetos sin parar, ha llegado a una forma perfecta de expresión, que sirve como cauce vehicular para toda su obra. A través de esta experimentación poética llega a borrar fronteras entre géneros, pues todo es, al fin y al cabo, poesía pura. Y es a partir de los testimonios del propio autor y de la documentación hallada en 
la Casa Museo de Miguel de Unamuno que llegamos a la conclusión de que el proyectado poemario de estos años, continuación del primero, Poesías, debió de derivar en este momento de la redacción en un libro de poemas en prosa.

\section{LOS POEMAS EN PROSA}

a. Un prólogo “crítico-apologético-poético”: algunas reflexiones teóricas a la luz de un borrador autógrafo

Algunas de estas composiciones fueron incluidas por García Blanco en sus antologías Don Miguel de Unamuno y sus poesías (1954) y Cincuenta poesías inéditas (1958). Según el hispanista salmantino, los poemas inéditos incorporados en sus colecciones forman parte de una lista ${ }^{4}$ que Unamuno escribió de su puño y letra con más de cien títulos, ordenados cronológicamente y acompañados, en algunos casos, de ciertos signos o asteriscos, indicadores de que ese poema, en concreto, ya había sido publicado. Para don Manuel, este elenco debió de ser redactado en torno a 1912 (Unamuno 1958: 14). En efecto, mientras que la mayor parte de estas composiciones vieron la luz en revistas, diarios o formaron parte de otros poemarios, como Rimas de dentro (1923) o Andanzas $y$ visiones españolas (1922), cerca de un centenar fueron descartadas por don Miguel para su publicación, siendo desconocidas para el público hasta los florilegios póstumos.

Asimismo, al frente de las Cincuenta poesías inéditas, el editor inserta el borrador de un prólogo escrito por Unamuno para este nuevo poemario, que vendría proyectando desde 1907. Con el fin de no tergiversar el contenido del proemio, don Manuel decide reproducirlo «en el estado de redacción a que había llegado» (Unamuno 1958: 20). Del mismo modo, justifica la elección de los poemas seleccionados por presentar estos una «redacción definitiva, dispuesta ya para la imprenta. Otra cosa parecería traicionar un propósito respetable». Aunque no dudemos de las buenas intenciones del editor, nos vemos obligados a precisar que los borradores de que dispuso para su edición no se pueden considerar, en ninguno de los casos, «copias de imprenta», sino más bien «copias en limpio» o versiones en un estado avanzado de textualización, pero que aún presentan numerosas variables en el ámbito de la elocutio $^{5}$.

4 Don Manuel no facilita la localización de la mencionada cuartilla y nos ha sido imposible hallar dicho documento en el archivo de la Casa Museo de Miguel de Unamuno.

5 La crítica genética diferencia los borradores avanzados de las copias en limpio o manuscritos definitivos, considerando el primer tipo dentro de «la etapa que precede inmediatamente a la copia en limpio del manuscrito pre-definitivo, después del manuscrito final, que pertenecen a la fase pre-editorial, pero todavía pueden contener importantes transformaciones» (Biasi 2008: 109). 
Asimismo, habría que inscribir el mencionado prolegómeno dentro de un momento escritural determinado, entre mediados de 1912 y 1913 , cuando concibe la preparación de un libro de poemas en prosa. Por lo tanto, carece de sentido poner al frente del citado florilegio el borrador de este proemio como apertura de toda la colección, pues esta incluye composiciones escritas a lo largo de dos décadas, de 1907 a 1927.

Con respecto al prólogo, el mismo manuscrito de trabajo que utilizó García Blanco se encuentra archivado en la carpeta 69/53, formada por seis folios; quizás, reunidos en el legajo por el propio hispanista. Basamos esta hipótesis en el último folio del conjunto. Se trata de un sobre, en cuyo reverso aparece como remitente el primogénito de Unamuno, Fernando de Unamuno Lizárraga, mientras que en el anverso se puede leer, de letra del propio don Manuel, «Unamuno. Prólogo Poesías. [50 poesías inéditas]».

El primer folio contiene la versión del proemio publicada en 1958, para cuya lectura íntegra remitimos a la edición de García Blanco (1958: 27-31). La casi totalidad de las ideas aquí expresadas las fue dando a conocer nuestro autor en diversos escritos anteriores (y algunos posteriores). En él Unamuno justifica la elección de publicar sus versos con la forma tipográfica de la prosa por tres motivos: el primero, como reacción a la moda imperante y desmesurada de quienes creen editar poesía por el simple hecho de disponer el texto en «renglones desiguales»; en segundo lugar, por la ventaja económica que supone una edición en prosa frente a la de versos; y, en tercer lugar, para ayudar a la lectura e interpretación de su poesía.

Publico esta nueva colección de poesías en forma tipográfica de prosa en parte por reacción contra el (exceso) contrario y es el de publicar prosa en forma tipográfica de versos o sea en renglones desiguales y en parte para ayudar a su mejor lectura e interpretación musical o rítmica.

Por otro lado, podemos fechar este borrador a partir del verano de 1912 , basándonos en tres datos: en primer lugar, la mención a la novela La pata de la raposa, publicada ese mismo año, y de la que Unamuno escribió una reseña publicada en La Nación el 13 de agosto de 1912. En segundo lugar, las citas a la Storia della letteratura italiana del historiador Francesco De Sanctis, cuya lectura, según nos consta, no emprendió don Miguel hasta el verano de ese mismo año.

Asimismo, cabría la posibilidad de posponer su fecha de redacción, pues este proyecto se mantuvo vivo en la mente de su creador hasta, por lo menos, los primeros años de la década de los veinte. Sin embargo, ya que todos los manuscritos de trabajo de los poemas en prosa localizados están datados por Unamuno entre el 2 de julio de 1912 y el 14 de julio de 1913, optamos por considerar la escritura del prólogo en estos meses. Además, deberemos tener en cuenta el tercero de los datos anteriormente aludidos, y que consiste en la 
referencia que Unamuno realiza de su artículo «El árbol y el libro», publicado en Los Lunes de El Imparcial el 7 de abril de 1913. Este apunte haría precisar aún más la datación del autógrafo, situándolo entre abril y julio de ese año. Este ensayo, que su autor dice haber escrito en El Escorial, «donde junto a un hermoso bosque hay un Monasterio con una biblioteca de librotes antiguos, y donde también está la Escuela de Montes con su biblioteca correspondiente» (Unamuno 1966a: 1004), le sirve al rector de la universidad salmantina de excusa para plantear la siguiente cuestión: ¿es más importante el libro o el árbol?, ¿las bibliotecas o los árboles? Partiendo de este interrogante, llega a una «terrible» e irónica conclusión: «desamortizar los archivos y bibliotecas», seleccionando con rigor los libros allí custodiados, «y dejando en ellos lo estrictamente necesario para la cultura humana, que es lo menos, llevar todo lo demás, es decir, casi todo, a las calderas de las fábricas de papel y convertirlos en papelote», con el que fabricar nuevos libros. Asimismo, establece la oposición entre el hombre libresco, que lee por placer, y el bibliómano o bibliófilo, que tan solo tiende a conservar y almacenar los libros, sin tan siquiera haberlos abierto para hojearlos. De ahí que el autor también sugiera echar a las «calderas» a estos amantes del almacenaje libresco.

Siguiendo la línea marcada por Poesías (1907), Unamuno pretende dar a conocer en un segundo volumen de versos la novedad técnica que suponen sus poemas, hechos «a oído» y «no a ojo». De la misma forma, en repetidas ocasiones expresa su disconformidad con el desconocimiento que se tiene de la poesía en España, lo que conduce a la predilección por las rimas «de tamboril» de Zorrilla e insiste en la necesidad de instruir al público en la correcta lectura de sus poemas. En este sentido, el parangón con Wagner y el rechazo que sufrió su obra por parte del sector musical más conservador, le sirve para justificar el desdén que ciertos eruditos y lectores sintieron por sus versos ${ }^{6}$.

En efecto, para que su lírica sea verdaderamente comprendida, antes el público y los propios representantes y transmisores de la poesía deben estar educados en la nueva técnica. Así, carece de todo sentido que actores, diestros en los ritmos de Zorrilla, como Rafael Calvo, intenten siquiera recitar sus poemas, pues el resultado será desastroso. Por otro lado, para ilustrar que lo característico de la poesía no es la rima, sino el ritmo, recurre en numerosas

${ }^{6}$ «Y ocurre otra cosa, y es que no saben leer. Cierta música, la de Wagner, v.gr., tardó en entrar y no solo porque como empezaron a tocarla y cantarla ejecutantes y cantantes educados en la otra, la destrozaban. Un tenor de la escuela de los que cantan las arias de Donizetti y Bellini no podía cantar adecuadamente Lohengrin o Tannhäuser. Esta música no ha sonado hasta que no la han cantado y tocado virtuosos que formaron su virtuosismo cantándola y tocándola. Y así nos sucede. Si uno de aquellos que se hicieron la boca y el oído en la declamación enfática, isocrónica o canturreante de Zorrilla o de Núñez de Arce o en las de las melopeas modernistas se pone a leer los cantos de usted [Ernesto A. Guzmán] y/o mis salmos los destroza» (Robles 1996: 336). 
ocasiones a la anécdota del quiosco de su pueblo, en torno al que se reunían los vecinos en fiestas $\mathrm{y}$, acostumbrados como estaban a bailar siempre lo mismo, cuando la banda cambia el registro y emprende la ejecución de una música diferente, nadie sabe seguir el ritmo ${ }^{7}$.

Unamuno mantendrá a lo largo de toda su trayectoria la misma postura de rechazo ante la música de «organillo» y «bailable», tan del gusto del público y no cejará en su empeño de educar al mismo en la lectura de la nueva poesía, hecha con el «oído» y no a «ojo» (Unamuno 1969: 1345). La única variación que se observa a lo largo de estos años concierne a la rima. Después de publicar su primer poemario, continúa remarcando que su poesía no proviene de la forma, sino del fondo: «He tendido a que mis poesías lo sean de contenido poético, convencido de que el ritmo brota de este» (Robles 1996: 276), rechazando la rima por ser demasiado «sensual», «desviadora» o «tirano empurpurado» (Robles 1996: 347), útil solo para aquellos que escriben poesía de fuera a dentro, como Rubén Darío, que «necesita de la rima para enlazar y dar coherencia a sus concepciones poéticas, que suelen ser caleidoscópicas y faltas de lazo interior» (Robles 1996: 276). Sin embargo, como hemos mencionado anteriormente, poco a poco irá matizando su animadversión hacia la rima generatrice, aceptando su uso cuando surge de forma espontánea, sin «malabarismos». De esta forma, vemos cómo a lo largo de 1910 prepara un nuevo tomo de versos, en el que experimenta la disociación de la rima y el ritmo. Y, aunque entre finales de 1910 y principios de 1911 compone un poemario formado íntegramente por sonetos, insiste en que la música exterior debe estar siempre supeditada a la interior, y no viceversa. Así, el 3 de marzo de 1911 publica el artículo, «El desinterés intelectual», en el que reconoce la valía de la tan aborrecida hasta el momento rima genetrice, a la que otorga el mérito de ser creadora o sugeridora de nuevas ideas. Esta postura que podría parecer contradictoria se justifica subrayando que su aversión se centra en el abuso modernista de la rima. Mientras el modernismo tan solo se propone «alterar el valor de cada verso, individualmente considerado, cambiar su acento, etc.», buscando las rimas «ricas», Unamuno se distancia de sus contemporáneos combinando libremente los metros tradicionales («viejos versos») y sin rima, a fin de liberarla «de la fórmula». Y solo teniendo en cuenta esto se podrá comprender

7 «En derredor del quiosco de la música de mi pueblo se reunía antaño el pueblo a bailar. Se afinó la banda, empezó a tocar en vez de valses, polcas y mazurcas, sonatas y trozos de ópera y aquella gente intentó bailarlos. Intentó bailar a Wagner, a Beethoven, y al ver que no podía bailarlos, llevarles el compás con los pies, declaró que ni aquello era música ni cosa que se le parecía. Y así les sucede a los del caramillo y es que llevan el compás con los pies, aun sin saberlo. Cuando no pueden acompañar algo con su albogue pánico, para que sus damiselas bailen en el pic nic turrieburnesco declaran que aquello no es música ni cosa que se le parezca. Hablan de oído y de música, y tienen la música en los pies o... en los dedos» (Robles 1996: 337). 
los apuntes de su prólogo: «Yo modernista no! Cada ladrillo en combinar. No ridiculez tampoco de nuevas combinaciones simétricas de viejos versos». Entre los «malabarismos» a evitar destaca el incorrecto empleo de algunos monosílabos, forzado por poetas como Leopoldo Lugones al rimar «náyade» con «háya-de». Esta es la violencia lingüística, no natural y, por tanto, no armónica, contra la que lucha constantemente Unamuno:

Cuando le sale a uno la rima bien va, pero hay que acabar con los malabarismos de la rima. El otro día vi rimados haya de con náyade, y aun cuando esto no es un disparate como rimar de con sé o sin con confín, suponiendo equivocadamente que todos los monosílabos españoles son tónicos, cuando las preposiciones y otros muchos son átonos proclíticos, aunque no es tan grande disparate sigue siéndolo en parte pues no se dice háya-de resultar sino háya de-resultar. En rigor suena háyade con náyade, pero es una violencia (Robles 1996: 336).

Por otro lado, la mayor novedad técnica que Unamuno defenderá con insistencia en sus escritos será el empleo de las silvas en versos libres de cinco, siete, nueve y hasta once sílabas, a cuya composición ha llegado «a posteriori». La predilección por este tipo de estrofa de la tradición italiana la manifestó nuestro poeta en numerosos escritos, tanto públicos como privados, por eso en las notas autógrafas de su proemio le basta tan solo con trazar la siguiente indicación: «Silvas de 11, 9, 7, 5, sin rima, libres», para saber perfectamente qué tenía que desarrollar en esa parte del prólogo. En efecto, será este tipo de estrofa la que llevará a la práctica en los manuscritos de trabajo para dar forma a sus poemas en prosa, de versos libres o rimados (en consonante o asonante):

En unos versos libres no puede meterse asonantes. Por qué? Porque suenan mal. Mentira! El oído preceptivo, las silvas de versos de once, siete y cinco sílabas mezclados? Es el mismo ritmo. [...] Y como por otra parte un decasílabo son dos de cinco, entra también éste y también el de seis que con él concuerda. Todo depende del arte de las transiciones [Ms. 69/53, fol. 1, r.].

A fin de justificar su teoría del ritmo, don Miguel se apoya en las citas de diversos autores. Aunque no es nombrado de forma explícita en el prólogo, resulta evidente que la lección del historiador francés Leon Gautier está bien presente en el hológrafo; sobre todo, teniendo en cuenta que el segundo y tercer folio de la carpeta 69/53 contiene un fragmento del texto en francés de la Histoire de la langue et de la littérature française, acompañada de su correspondiente traducción al español. A continuación, pesentamos la transcripción diplomática del borrador contenido en el folio 2:

Prólogo poesías:

"La asonancia es un procedimiento de los tiempos primitivos - hace cien años se habría dicho 'bárbaros'- cuando se escucha nuestros viejos poemas y no se los lee... porque no se sabe leer. Pero pronto vendrá tiempo más civilizado y entre 
los oyentes de nuestras canciones habrá más de uno que tome verdadero gusto en leer nuestros romans y pedir copia de ellos. Durante la primera época que es la de la ignorancia, la asonancia basta para todo: porque está hecha para los oídos y no para los ojos. Pero los letrados no se contentaron con ello y hubo un día que satisfacerles. De aquí la rima". Leon Gautier, en el cap. II La epopeya nacional de La Hist. de la Letterature française des Origins a $1900 \ldots$ publiée sous la direction de L. Petit de Julleville [Ms.69/53, fol.2, r.].

A pesar de que no se haya conservado ningún ejemplar en la biblioteca de la Casa Museo de Unamuno, sabemos que don Miguel leyó los escritos de Gautier desde bien temprano. Así, su teoría sobre el origen ancestral de la asonancia ligada a la literatura oral y su paulatina sustitución por la rima, derivada esta de la lectura silenciosa, inspira a nuestro autor para justificar su preferencia por los versos asonantes y libres en estructuras métricas donde en castellano primaba hasta entonces el consonante. De ahí que insista en repetidas ocasiones en que sus versos son hechos por y para el oído, tal y como fue en su origen.

Los otros dos eruditos en los que se apoya don Miguel para fundamentar su tesis son el historiador italiano Franceso De Sanctis y el escocés Robert Louis Stevenson, presentes ambos en los apuntes autógrafos del folio 4 de la misma carpeta 69/53:

Para el prólogo:

Né in questa forma sgraziata, che voul essere poesia e non è prosa... Fr. de Sanctis, Storia della letteratura XIII L'Orlando furioso, hablando de unas comedias en esdrújulos con que Ariosto quiso imitar los yambos latinos.

v. Stevenson, sobre Walt Whitman [Ms. 69/53, fol. 4, r.].

Aunque no podemos asegurar en qué fechas fueron redactados estos apuntes, suponemos que los folios 2, 3 y 4 consistían en una especie de notas que Unamuno iba extrayendo de sus numerosas lecturas y que, posteriormente, le sirvieron, a su vez, de borrador para la extensión del prólogo, folio 1. Esta forma de escribir podría recordar a la escritura ovípara que empleó para la redacción de su novela Paz en la guerra. Sin embargo, insistimos en que no tenemos constancia de que Unamuno redactara expresamente estos apuntes con la intención de escribir este proemio, puesto que estas mismas ideas aparecen de forma recurrente a lo largo de toda su obra, tanto en artículos como en la correspondencia privada, anteriores a la publicación de Poesías, en 1907, y muy posteriores. Asimismo, esta forma particular de composición la identifica su autor con el tipo de escritura orgánica, cuando en su ensayo «Sintaxis mecánica» (1921) sostiene que:

Todo escritor que tenga estilo, verdadero estilo, no manera, que cree orgánicamente y no que construya mecánicamente la expresión de su sentir y de su pensar y su imaginar, ha dicho antes lo que ha escrito después. Si no a otro, se lo ha 
dicho a sí mismo. Y hay hasta quien se dicta a sí mismo, y en voz alta, mientras va escribiendo a su por qué dictado (Unamuno 1969: 879).

Volviendo al análisis del autógrafo, el folio 4 contiene dos anotaciones sobre dos obras, incluidas también en el esbozo del proemio de la carpeta 69/53. Se trata, por un lado, de la Storia della letteratura italiana de Francesco De Sanctis y, por otro lado, de los Familiar Studies of men and books de Stevenson. Así como resulta imposible datar las lecturas de sendos ensayos de Gautier y de Stevenson, poseemos la certeza de que no leyó el estudio del historiador italiano hasta la primavera del año 1912. En carta del 15 de junio de 1912 dirigida a Giovanni Amendola manifiesta su intención de comenzar la lectura de la Storia en breve, por recomendación de Benedetto Croce (González Martín 1978: 159). Este dato se revela de suma importancia para fechar el prólogo a partir del verano de 1912 y circunscribirlo a un momento de la redacción determinado.
Hablando de las comedias en versos esdrújulos que querían reproducir los yambos de Ariosto, dice de Sanctis (Storia della letteratura italiana, XIII) que "ne in questa forma sgraziata, que vuol essere poesia e non è prosa". Y Robert Louis Stevenson (Familiar estudies [sic] of men and books) en un estudio sobre Walt Whitman, este "perrazo hirsuto, recién desencadenado, que recorre las playas del mundo ladrando la luna" habla de cómo escojió [sic] un verso rudo, no rimado, lírico y dice "I believe myself that it was selected principally because it was easy to write". Según el mismo Whitman era romper las barreras entre la prosa y la poesía. (Más bien volver a la unidad de que se diferenciaron). No quería tomarse la molestia de escribir prosa; son como notas, como cosas dichas a sí mismo, sin acabar. Son soliloquios. De aquí su fuerza: y su flaqueza [Ms. 69/53, fol.1, r.].

Si cotejamos las notas del folio 4 con la cita en el folio 1, comprobaremos que, sin lugar a dudas, el primero sirvió de borrador para el segundo. Unamuno pretende demostrar, invocando a la auctoritas, que otros ya antes que él habían recorrido el mismo camino que les llevó a una forma «que vuol essere poesia e non è prosa». Así, Ariosto introduce la novedad en sus comedias de los versos en esdrújulos, y Walt Whitman llega a un tipo de verso con el que «rompe las barreras entre la prosa y la poesía». Sabemos con seguridad que su lectura de los Familiar studies of men and books (1882) fue bastante anterior a la del erudito italiano, pues se encuentran citas a los comentarios que Stevenson realizó sobre Whitman repartidos en diversos escritos de Unamuno. Además, se conserva una edición del mismo, en la biblioteca personal de don Miguel, del año 1903, por lo que adelantamos su lectura, al menos, nueve años antes de la de De Sanctis.

En efecto, la primera mención que hemos localizado de Stevenson se remonta a 1906. En un artículo titulado «El canto adámico», publicado el 6 de agosto en Los Lunes de El Imparcial, parte de la lectura que le inspiró las 
Leaves of Grass del poeta americano, a quien define como «enorme embrión de un poeta secular, de quien Roberto Louis Stevenson dice que como un perro lanudo, recién desencadenado, recorría las playas del mundo ladrando a la luna; tomé esas hojas y traduje algunas a mi amigo, ante el esplendor silencioso de la ciudad dorada».

La segunda cita la hallamos en otro artículo, "Sobre el estilo de Martí», publicado en La Discusión de La Habana, el 21 de noviembre de 1919. A pesar de ser este ensayo posterior a la redacción del prólogo autógrafo, consideramos conveniente su inclusión en este apartado, ya que demostraría que estas notas las empleó su autor para varios escritos. Como bien se desprende del título, don Miguel pasa a disertar sobre el estilo del poeta cubano, partiendo de unas reflexiones que le suscitó la obra de Stevenson sobre la poesía de Whitman:

En el ensayo que en sus Familiar Studies of men and books dedicó Roberto Louis Stevenson a Walt Whitman, nos dice hablando del estilo de este formidable profeta de la democracia norteamericana: "Ha escojido [sic] un verso rudo, no rimado, lírico; a las veces tocado de un bello movimiento procesional; a menudo tan abrupto y descuidado que sólo puede describirse diciendo que no se ha tomado la molestia de escribir prosa”. Y este último concepto fue para mí una revelación (Unamuno 1958: 579).

Whitman fue un referente para Unamuno por su pretensión de romper con los límites que separan la prosa de la poesía, y las palabras del crítico escocés le llevan a la conclusión de que es erróneo pensar que el verso procede de una reorganización de la prosa ritmoide, así como la prosa sea una reducción del verso. Ambos, verso y prosa, proceden de «una forma de expresión protoplasmática», presente en los salmos hebraicos y en los versos de Whitman y de Martí: «No hay en ellos más freno que el ritmo del endecasílabo, el más suelto, el más libre, el más variado y proteico que hay en nuestra lengua. Y más que un freno es una espuela ese ritmo; una espuela para un pensamiento ya de suyo desbocado».

Según Isabel Paraíso (1985: 218), Unamuno utiliza la expresión «verso libre» de dos formas diferentes: entendiéndolo como verso suelto, sin rima, o bien como Urpoesie, es decir, «estado protoplasmático de la expresión anterior a la prosa o el verso». Al menos en otras dos ocasiones, don Miguel reflexiona sobre esta naturaleza protoplasmática de la lengua, a la que llega a definir como algo «que ni es prosa ni es verso, con una sintaxis de lenguaje interior»; sintaxis que es «dinámica» y no «mecánica». Asimismo, cuatro años más tarde en los apuntes que escribe sobre «El estilo de Galdós» retoma esa misma definición atribuyendo a esa «forma protoplasmática» «un carácter enigmático, elíptico, telegráfico, en que uno se habla a sí mismo», coincidente con la expresión del pensamiento, «anterior a la diferenciación de prosa y verso, en que tomamos nuestras notas para uso individual» (Unamuno 1969: 915). En el propio borrador del prólogo, don Miguel concluye estableciendo la identificación entre el 
verso y la prosa «ritmoide», diferenciándola a su vez de la prosa común por no estar está compuesta «intencionadamente y adrede en número rítmico». Y, sin lugar a dudas, será el endecasílabo el verso que asocie a este «número rítmico», apto como expresión vehicular, independiente de la forma adoptada.

$\mathrm{Si}$ atendemos a la parte final del borrador del prólogo, dedica las últimas líneas a describir la naturaleza del endecasílabo, nacido este de la «fusión o engarce» de diferentes metros, no de una «mera yuxtaposición». Así, un endecasílabo puede formarse a partir de la unión de un pentasílabo y un heptasílabo, también llamado de gaita gallega, o viceversa, siempre y cuando se produzca el hiato entre la última y la primera sílaba de ambos. En este punto, conviene detener nuestro estudio en el penúltimo folio de la carpeta 69/53, cuyo contenido, a continuación, transcribimos:

Endecasílabo

Es el verdadero hexámetro moderno, el verso heroico, el orgánico y no mecánico.

Los de $147+7$, los de $126+6$ o $8+4$

Los de $84+2$, o $5+3$. Los de $105+5$ o $6+4$

$\mathrm{S}$ El endecasílabo

$\begin{array}{lllllllllll}1 & 2 & 3 & 4 & 5 & 6 & 7 & 8 & 9 & 10 & 11\end{array}$

$$
\overline{1} \overline{2} \overline{3} \overline{4} \overline{5}
$$

Con acento en $6 .^{\mathrm{a}}$ y $10 .^{\mathrm{a}}$ o de gaita gallega.

Sección aurea, [ilegible]

$$
\begin{array}{rr}
1-2-3-5-8-13-21-34-55-89-144 \\
55: 89:: 89: 144 & 144 \times 55=7920 \\
89^{2}=7921
\end{array}
$$

$\begin{array}{ll}144 & 89 \\ \frac{55}{720} & \frac{89}{801} \\ \frac{720}{7920} & \frac{712}{7921} \\ \frac{22,05}{2=} & 22,05 \\ 11,025\end{array}$

El endecasílabo se ha convertido en el metro por excelencia de la poesía castellana. De ahí que se refiera a él como el «verdadero hexámetro moderno», «orgánico» y «no mecánico». Y esta definición del endecasílabo como orgánico habría que vincularla con el final de las notas, donde transcribe la expresión «Sección áurea» y la secuencia matemática de Fibonacci. Para solucionar un problema técnico sobre la reproducción de los conejos, Leonardo, llamado el Pisano o de Fibonacci (s. XII), desarrolló la primera serie recursiva conocida en Europa, donde cada número se obtiene a través de la suma de los dos ante- 
riores. En el siglo XVIII, el matemático Robert Simson creó una nueva secuencia numérica, calculando cada término a partir de la división de los términos sucesivos de la serie de Fibonacci (Rincón 2004: 79). Así 1/1=1; 2/1=2; 3/2=1,5; $5 / 3=1,67 ; 8 / 5=1,6 ; 13 / 8=1,625 ; 21 / 13=1,62$, etc., en una sucesión infinita, pero que cada vez se va aproximando más a un número ideal, el número áureo o phi $(1,61818)$.

Tanto la serie de Fibonacci como el número phi representarían el patrón natural del universo, por el que se rigen todos los organismos vivos, revelando «el secreto de las proporciones humanas, el ideal de lo bello y lo sublime». Por lo tanto, es preciso no entender este número dorado como una cifra en concreto, sino como una relación de proporciones. No en vano recibió el nombre del escultor más famoso de la Antigüedad, Fidias, por representar este en sus esculturas la perfecta proporción entre las partes, y la armonía y la belleza en la simetría.

A partir del análisis de los manuscritos de trabajo, se observa cómo Unamuno tuvo, al menos, la voluntad de desarrollar una secuencia áurea en poesía, semejante a la serie del matemático pisano, donde el número 11 se correspondería con el número dorado o número rítmico. De esta manera, habría que concebir el poema como organismo, pues en su estructura se reflejaría el mismo patrón de proporciones simétricas, presentes en el resto de seres vivos. En efecto, sería el endecasílabo el verso de perfección armoniosa y, no por casualidad, en el folio 5 de la carpeta 69/53, aparece mencionado Santillana y, a continuación, el esquema tantas veces plasmado en diversos escritos, del endecasílabo de gaita gallega; metro que el Marqués cultivó reiteradamente en su proceso innovador de adaptación del soneto italiano a la lírica castellana (Lorenzo Grandín 1987-1989: 785). Unamuno reconoce para el endecasílabo su carácter orgánico, no mecánico, por nacer de la «fusión o engarce», que no «yuxtaposición» de un heptasílabo y un pentasílabo. Sin embargo, esta es solo una de las múltiples combinaciones, que siempre darán como resultado el número 11, o una cifra aproximada $(11,02)$. Así, identifica el mismo ritmo en sus silvas formadas por la unión de versos de once, siete y cinco sílabas, y justifica esta amalgama por haber sido concebidas «a oído», no con el pensamiento o «a ojo». Por lo que, insiste, producen música, no «de pianola» o «de organillo», tan del gusto del público mayoritario. Además, la organicidad de este tipo de verso se refleja, del mismo modo, en la espontaneidad, característica de los seres vivos, presente en la lengua empleada y la rima. Por esto rechaza con rotundidad los «malabarismos» modernistas, que dan lugar a rimas forzadas, no naturales. Todos los elementos serán bien aceptados siempre y cuando sean el resultado de una creación organicista, es decir, natural, espontánea y, en cierto sentido, instintiva e irreflexiva, que como bien señaló La Rubia Prado (1996: 20), se identifica en Unamuno con la escritura vivípara. Por el contrario, la escritura ovípara o mecanicista, aunque practicada en numerosas ocasiones, será finalmente repudiada por basarse en el artificio y la erudición externa. 


\section{b. Análisis de los borradores de los poemas en prosa}

En efecto, gracias al análisis de los manuscritos de trabajo de poesía conservados en la Casa Museo, constatamos cómo don Miguel llevó a la práctica todas las reflexiones apuntadas en el borrador del prólogo a lo largo de 1912 y 1913. De esta forma, se podría establecer una nómina que reuniría unas diecisiete composiciones, cuyos borradores reflejan esa voluntad de cancelar las fronteras entre el verso y la prosa. Once de ellas fueron publicadas de forma póstuma en la antologías de García Blanco, Don Miguel de Unamuno y sus poesías (1954) y Cincuenta poesías inéditas (1958), mientras que el resto las incluyó su autor en el conjunto de las «Visiones rítmicas» de Andanzas y visiones españolas (1922); libro con el que Unamuno logra, finalmente, fundir la prosa y el verso en un mismo discurso poético y donde, como ya apuntó su discípulo (1958: 31), retoma las reflexiones apuntadas en el borrador de 1912 1913 para introducir sus «visiones».

A pesar de que el antólogo decide editar los poemas con la forma tipográfica del verso, las «copias en limpio» localizadas de todos ellos revelan el propósito de su autor de publicarlas a renglón seguido. Sin embargo, del cotejo de los manuscritos consultados se desprende que don Miguel concibió todas estas composiciones en verso y que solo, en un último momento de la escritura, decidió dotarles de la forma tipográfica de la prosa.

Deberemos considerar como la primera de todas la titulada «Al zorro», inspirada en la lectura que le suscitó la novela La pata de la raposa, de Pérez de Ayala. En la reseña que realizó Unamuno de la misma en el mes de julio de 1912 y publicada, posteriormente, en La Nación de Buenos Aires el 13 de agosto, don Miguel menciona la génesis de este poema, surgido a partir de la lectura de la cuarta novela del escritor ovetense. En efecto, el recurso le sirve de excusa para anunciar ante el público la inminente publicación de su tercer libro de poesía, donde esta vez se ha resuelto a editar sus versos rimados en la forma tipográfica de la prosa. El texto del poema es idéntico a la versión de la copia definitiva, salvo en dos casos, uno de ellos probable errata del editor o cajista de la revista: el primero está relacionado con la mala fama de que goza el zorro, asociado siempre a la «listeza», por lo que no tiene ningún sentido que en el texto se sustituya por «tristeza». En cuanto a la segunda palabra, pensamos que la versión de la revista posee la lección correcta. Hacia el final del poema leemos: «que en armar cepos usas de artimañas», mientras que en la copia en limpio el verbo aparece en tercera persona del singular, «usa». Puesto que a lo largo de toda la composición el poeta se dirige a un «tú», desde el mismo título de «Al zorro», consideramos que la opción correcta sería la que presenta el verbo en la segunda persona del singular y que la variable del manuscrito de trabajo se deba a un error de copia de Unamuno; lo que, por otro lado, no sería infrecuente en su práctica escritural, tal y como lo reconoció él mismo en más de una ocasión. 
De esta composición, además del texto publicado en la revista, se han conservado otros dos borradores diferentes, reunidos en una misma carpeta con la signatura 61/31. Esta está formada por un total de cinco folios, de los que el último se correspondería con un sobre escrito en el anverso por García Blanco, donde se indica el título de la composición, y la fecha y el libro en el que fue incluido, «Sueltas XXVI», es decir, en la antología de 1954, Don Miguel de Unamuno y sus poesías. Los tres primeros folios coinciden con la «copia en limpio» del poema, mientras que el cuarto contiene un borrador anterior en un estado avanzado de redacción. Para la extensión de este último, Unamuno reutiliza la mitad de una carta que lleva el membrete de la Comisión Provincial de Monumentos Históricos y Artísticos de Salamanca y donde se insta al Sr. Rector de la Universidad Literaria de Salamanca para que acuda el día 15 de junio de 1912 al despacho del Gobernador Civil. La misiva está fechada un día antes de la reunión, el 14 de junio.

Como se infiere del análisis y cotejo de ambos hológrafos, don Miguel concibe este poema en la forma tipográfica de la lírica, por lo que presta una especial atención al número de sílabas de cada verso, que transcribe en cifra en el margen derecho de la página. Sin embargo, para la versión en limpio y la definitiva aparecida en la revista escoge presentar dichos versos simulando un escrito en prosa. Salvo en dos ocasiones, Unamuno opta por los versos impares y sospechamos que esto no sea casualidad. Si volvemos al borrador del prólogo, junto a la primera referencia a La pata de la raposa observamos el número de una página, el 314. Si se procede a consultar un ejemplar de la primera edición de la novela, se puede leer cómo el protagonista, Alberto, preso de una efervescencia lírica, recita unos poemas por él compuestos a su novia Fina. Resaltamos de esa página el siguiente párrafo, destacando ciertas palabras clave mediante cursiva:

Prefería [Alberto], con sensitiva dilección, los metros impares, según aquel dicho de los antiguos: numero Deus impari gaudet, percibiendo en ellos más refinada armonía que en los pares, y una gracia incierta y flotante de inestabilidad que es adecuada correspondencia de ese último vaho o comezón en el ápice del espíritu, en cuyo seno vibran los requerimientos líricos. Procuraba también que los versos vivieran en un curso ondulante, fundiéndose unos en otros y todos ellos en una atmósfera tónica común; y para ello apelaba sin reparo al recurso que los retóricos llamaban encabalgamiento, que es al metro lírico lo que las notas ligadas al violín, o lo que el modelado aéreo de las pinturas leonardescas.

Unamuno distinguió estas líneas no en vano, sino porque en ellas se refleja gran parte de la poética que venía desarrollando en torno a esos años. Esa predilección por los «metros impares» por ser más «armónicos», se podría poner en relación con el folio 5 de la carpeta 69/53, donde se considera el endecasílabo como número áureo u orgánico. Y como tal, nace de la espontánea y natural «fusión» o «engarce» de versos de distinto número, y al igual que 
para Alberto, los suyos se funden «en una atmósfera tónica común». Asimismo, destaca el recurso al encabalgamiento del que don Miguel se manifestó partidario, hasta el punto de componer « $\mathrm{Al}$ zorro», prácticamente, basándose en esta figura retórica.

Si seguimos un orden genético-cronológico, la segunda composición que deberemos tener en cuenta es el soneto que comienza con el verso «Tallar quiero mi ensueño a todo brazo». La primera noticia que se tiene de esta composición nos la da García Blanco (1954: 169). Fue enviada por don Miguel a Roman Jori en carta del 21 de febrero de 1911, junto con otros cuatro sonetos que incluirá Unamuno en su Rosario de Sonetos Líricos. En total, se conservan cuatro versiones diferentes del poema. Además del autógrafo enviado a Jori, disponemos de un manuscrito de trabajo fechado el 2 de julio de 1912, de un texto publicado en Los Lunes de El Imparcial el 2 de septiembre de ese mismo año y de un último borrador inédito.

Tallar quiero mi ensueño a todo brazo, con pico en un granítico berrueco, y no en bronce, sonoro por lo hueco, fundirlo; y al moderle luego el trazo sol, hielo y musgo, sobre el espinazo del páramo, como él ardiente y seco, roca viva será, que no un muñeco del arte vil. Y así, en su regazo, mi patria adentrará mi ensueño, su hijo, que es roca de su roca y es verdura de su escaso verdor.

[tercetos]

sólo haciéndose tierra se perdura [Carta del 21 de febrero de 1911]

Tallar quiero mi ensueño a todo brazo con pico en un granítico berrueco, y no en bronce, sonoro por lo hueco, vaciarlo; y al morderle luego el trazo sol, hielo y musgo, sobre el espinazo del páramo, como él ardiente y seco, roca viva será, que no un muñeco del arte vil, para la carne lazo.

Y no en pulido mármol, en granito, entraña de mi tierra, áspero y duro, que en Gredos se levanta al infinito, vencedor del pasado y del futuro, sobre las nubes del presente un hito de eternidad, y de la patria un muro! [Ms. 64/38, fechado el 2 de julio de 1912]

Tallar quiero mi ensueño a todo brazo con pico en un granítico berrueco, y no en bronce, sonoro por lo hueco, vaciarlo; y al morderle luego el trazo sol, lluvia y musgo, sobre el espinazo del páramo, cual él ardiente y seco, roca viva será, que no un muñeco del arte vil. . [Los Lunes de El Imparcial, 2 septiembre 1912]. 


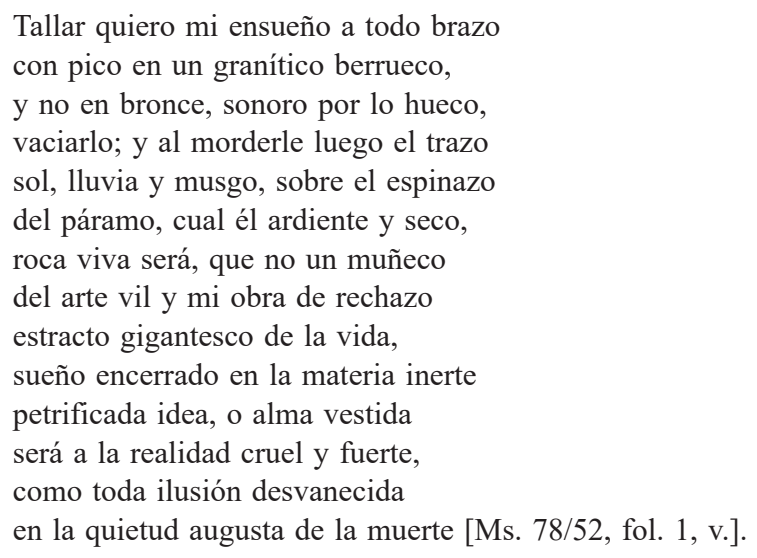

Como bien se aprecia del cotejo de las versiones, este poema pasó por diversas fases de escritura, hasta que, finalmente, Unamuno, en apariencia no satisfecho con el resultado adoptado, se decidió a publicarlo incompleto. En la primera extensión de 1911, donde nosotros hemos resuelto transcribir «tercetos», don Miguel incluye una especie de advertencia a su corresponsal: «Me falta completar los tercetos, hasta acabar». Sin embargo, vemos que en la segunda versión el poema ha cambiado por completo. Mientras los cuartetos se mantienen casi intactos, los tercetos se han modificado por completo. Creemos que el principal factor que afectó a esta alteración tan brusca haya sido la rima, al haber reemplazado el consonante en -ijo, -ura por -ito, -uro. Pero no solo eso, sino que en este manuscrito de trabajo, que es una evidente «copia en limpio» del poema, transcribe el soneto a renglón seguido, prescindiendo de la forma tipográfica del verso, y distribuyendo las dos partes de la composición, cuartetos y tercetos, en dos párrafos distintos. Por el contrario, en el texto publicado en la revista unos meses más tarde, observamos de nuevo una variación en la elección de la disposición gráfica de los versos. Aquí los tercetos han sido eliminados, mientras la estructura de los cuartetos se mantiene sin apenas grandes modificaciones: tan solo dos variables con respecto a la versión autógrafa anterior.

No obstante don Miguel excuse la edición inacabada de ese soneto aduciendo que le ha sido imposible terminarlo («porque cuando una cosa no me sale de uno, dos o a lo sumo tres tirones, tengo que dejarla»), pensamos que es del todo intencionado, teniendo en cuenta el propio rótulo del ensayo en el que se inserta la tercera versión, «Sobre el fragmentarismo» (Unamuno 1969: 838-841). De esta forma, el poema incompleto, fragmentario, le daría pie para ejemplificar y desarrollar su teoría sobre la escritura vivípara frente a la ovípara. Claramente, ya desde el título se alude al género característico del romanticismo, el fragmento, «considerado como la encarnación más distintiva de su originalidad y el signo de su moderna radicalidad» (Lacoue-Labarthe 2012: 80). 
Por lo tanto, en el citado artículo, su autor manifiesta de forma explícita su concepción del poema como obra orgánica. Al igual que en otras composiciones, recurre en este caso a la imagen del poeta-escultor, del que distingue dos tipos: por un lado, aquel que modela primero su obra en barro, revistiéndola de bronce; y, por otro lado, el que esculpe su obra a partir del mármol o de granito sin más ayuda que un simple cincel y martillo. Para Unamuno, el resultado del primero tendrá siempre un carácter artificial, será «muñeco de arte vil», mientras que el trabajo de modelación del segundo estará siempre supeditado al azar, al devenir, pues «cada golpe de cincel es irreparable y cacho que se hace saltar no cabe volver a pegarlo», lo que obliga a variar el plan que se tenía en mente, pero de una forma espontánea y natural, y, por tanto, orgánica. Asimismo, esta obra esculpida en mármol o granito posee la capacidad de «fundirse mejor con la naturaleza», ya que sufrirá, de forma semejante al resto de organismos, los efectos de los agentes naturales, como la lluvia, el sol, el viento o el musgo, convirtiéndolo en «roca viva», como reza en las tres copias del poema.

Finalmente, la cuarta versión hasta ahora desconocida del soneto vendría a corroborar el afán perfeccionista de Unamuno, quien se muestra como un escritor que vuelve en diversas ocasiones sobre lo ya escrito y no duda en operar cualquier tipo de reescritura, aun a riesgo de alterar profundamente la dispositio del poema. El cuarto borrador inédito de este soneto se conserva en la carpeta 78/52. Para su extensión, el autor ha empleado una cuartilla, en cuyo recto observamos el recorte del texto publicado en Los Lunes de El Imparcial, seguido de una escritura en tinta negra, que presenta un trazo bastante precipitado e irregular. Quizás, el poeta preso de un momento de inspiración plasmó con rapidez los tercetos, en un último intento de completar el soneto.

Los siguientes ocho poemas de los que disponemos de una copia definitiva en prosa fueron publicados por García Blanco en su antología del año 1958. Aunque se conserve una copia en limpio de cada composición, tan solo han llegado hasta nosotros tres borradores de tres poemas. Los manuscritos definitivos presentan la particularidad de estar fechados por el propio Unamuno, salvo en dos composiciones, y muestran las mismas características físicas: para su redacción, el autor se ha servido de unas octavillas de tamaño 16 x 11, y ha empleado como útil de escritura una estilográfica de tinta negra, respetando los márgenes superiores y laterales y delimitando con claridad el espacio entre el título y el principio y final de la composición.

Si analizamos los manuscritos de trabajo de estos poemas, llegamos a unas conclusiones similares a las obtenidas para los dos casos anteriormente mencionados. Por los autógrafos hallados, es evidente que Unamuno concibió todos los poemas con la forma tipográfica tradicional del verso; sin embargo, las copias en limpio revelan su intención de publicarlas como prosa. Tomando como referencia las fechas señaladas por el propio poeta, la nómina de las composiciones sería la siguiente: «Oh si llegaseis a entender mis cantos», el 3 
de julio de 1912; «Repetición», 9 de julio de 1912; «Sentada estabas tú sobre la cima», 10 de julio de 1912; «Soñar... soñar... se sueña siempre solo», 13 de julio de 1912; «Anámnesis», 17 de julio de 1912; "Si vis pacem, age bellum», 1 de enero de 1913; «En la muerte de un amigo», 1 de marzo de 1913; y los poemas «Llueve» y «La guadañina», que García Blanco sitúa en julio de 1912 y 1913, respectivamente, a pesar de no indicar en qué datos se ha basado para otorgar esa cronología.

Al igual que en las composiciones incluidas en el florilegio póstumo de 1954, estas ocho reflejan la puesta en práctica de las reflexiones teóricas desarrolladas en el prólogo autógrafo. Así, podemos considerar las once como silvas libres de versos impares, donde los endecasílabos se mezclan en libre arbitrio con heptasílabos, pentasílabos, y algún tridecasílabo y eneasílabo. Únicamente en dos ocasiones («Al zorro» y «En la muerte de un amigo»), rompe con la medida impar de los versos e introduce algún cuatrisílabo. Esta peculiar combinación heterométrica de versos demostraría, una vez más, cómo Unamuno, siguiendo la estela marcada por sus contemporáneos, Ricardo Jaimes Freyre, Rubén Darío (Paraíso 2000: 199) o Manuel Machado ${ }^{8}$, se enmarca dentro de las líneas modernistas españolas 9 .

En cuanto a los endecasílabos, destaca la unión armónica de versos a maiore, acentuados en la $6 .^{a}$ sílaba, y sáficos, en la $4 .^{a}$. Asimismo, es preciso seña-

${ }^{8}$ Es bien conocida la admiración que los versos de Manuel Machado suscitaron en don Miguel por la búsqueda constante del ritmo y la música interiores, «alejados del simple juego formal estereotipado que inundó a otros modernistas [...] De ahí que Unamuno, enemigo acérrimo de las "modernisterías" poéticas, no tuviera empacho en afirmar las calidades rítmicas conseguidas por Manuel Machado» (Romero 1992: 199). A este respecto, recordamos la anécdota recogida por Machado en La guerra literaria, en la que cuenta el origen del término sonite, acuñado por él para justificar la novedad «retórica» de sus sonetos ante las críticas que estos despertaron en Eduardo Benot por no respetar la preceptiva clásica (Machado 1981: 114). Unamuno recoge esta misma anécdota y la pone en boca de uno de los personajes de Niebla para justificar así el nacimiento de un nuevo género narrativo, la nivola (Unamuno 1914: 158-159).

9 Aunque el propio Unamuno rechazó con rotundidad el vincular su nombre con sus contemporáneos modernistas, Juan Ramón Jiménez (1999: 126), en sus lecciones sobre el «Modernismo» de 1953, lo considera como el «modernista máximo» en España: «Es un hombre que va abiertamente en poesía contra las ideas, incluso contra las ideas religiosas. [...] No es que él (porque él no se unía con nadie), no es que se sume a ningún grupo, pero viene a ser lo mismo. En una forma diferente, es un hombre que explica sus ideas por medio de poemas, de una manera herética, exactamente como los otros». Esta línea crítica abierta por el moguereño, será retomada más tarde por estudiosos como Ricardo Gullón, Ricardo Senabre, Javier Blasco o Pilar Celma, entre otros, quienes, al margen de las obsoletas distinciones entre Modernismo y Generación del 98, supieron contextualizar correctamente la figura y obra de Unamuno dentro del marco del Fin de Siglo: «Con Unamuno el modernismo español se enriquece y adquiere profundidad. Él señaló un camino, que pronto siguieron [...] el resto de los modernistas» (Blasco et al., 2003: 13). 
lar la inserción en algunos de estos poemas del llamado endecasílabo de gaita gallega o endecasílabo dactílico, verso canonizado en nuestra literatura moderna por el nicaragüense Rubén Darío en 1892 (Domínguez Caparrós 2010: 7), lo que supuso una enorme novedad para la época. Contrariamente a lo que hasta ahora venía afirmando un sector de la crítica, Unamuno introduce en sus poesías este metro de carácter popular mucho antes de su Romancero del destierro, publicado en 1925 (Domínguez Caparrós 2010: 126). Así, en «Tallar quiero mi ensueño a todo brazo» plasma su teoría del endecasílabo de gaita gallega, heredado de la tradición española, con el verso: «entraña de mi tierra, áspero y duro», formado por la combinación de un heptasílabo y un pentasílabo y acentuado en la $6 .^{\mathrm{a}}$ y 10 . $^{\mathrm{a}}$ sílabas. De la misma forma, mientras retoma el esquema del endecasílabo galaico antiguo de la poesía popular gallega para «Oh, si llegaseis a entender mis cantos», donde introduce a lo largo de la composición tres endecasílabos acentuados en la 5. ${ }^{\mathrm{a}}$ y 10. ${ }^{\mathrm{a}}$ sílabas («de las vagas nubes que al sol se mecen [...] Es que sé yo, pobre de mí, perdido [...] tan solo que clama en el desierto»), remata el poema «Si vis pacem, age bellum» mediante dos endecasílabos dactílicos, pero de ritmo anapéstico, es decir, acentuados en la 4. ${ }^{\mathrm{a}}$ y $7 .^{\mathrm{a}}$ sílabas («y hacia Ti llévale sin que en $\mathrm{Ti}$ arribe [...] que con la paz en Ti muerte recibe»).

Como bien han señalado diversos estudiosos (Paraíso 2000: 199), Unamuno se sintió fascinado desde muy temprano por la silva libre modernista, cuyo molde, sin lugar a dudas, heredó del italiano Leopardi. Esta influencia foránea le lleva a experimentar con la rima, lo que le conduce a desarrollar un tipo de silva libre impar de rima consonante («Al zorro», «Tallar quiero mi ensueño a todo brazo», «Si vis pacem, age bellum» y «En la muerte de un amigo»), arromanzada, con rima asonante siempre («Sentada estabas tú sobre la cima», «Soñar... soñar... se sueña siempre solo», «La guadañina» y «Oh, si llegaseis a entender mis cantos»), o prescindiendo por completo de la rima externa («Repetición», «Llueve»y «Anámnesis»). Si bien Paraíso (2000: 200) otorga el honor a Juan Ramón Jiménez de haber sido el primer poeta español en consolidar la silva libre impar sin rima en el ámbito de la literatura hispana, en realidad, Unamuno ya en 1912 venía aplicando este tipo de innovaciones a su poesía.

Por otro lado, si atendemos al resto de manuscritos de trabajo de composiciones poéticas desarrolladas por don Miguel entre 1912 y 1913, comprobamos cómo no fueron estos inéditos los únicos poemas en prosa que concibió. A esta nómina inicial de once habría que añadir otros cinco, incorporados por su autor a las «Visiones rítmicas» de Andanzas y visiones españolas (1922) y otro no incluido en ningún poemario por su autor, «ßBienaventurados los pobres!». Sabemos que Unamuno editó en prensa algunas de estas «visiones» entre enero de 1912 y enero de 1914. Así, en las páginas de Los Lunes de El Imparcial da a conocer "Galicia», el 7 de octubre de 1912; «El Cristo yacente de Santa Clara», el 26 de mayo de 1913; «¡Bienaventurados los pobres!», el 14 de julio 
de 1913, y «Las estradas de Albia», el 26 de enero de 1914; y en La Estafeta, «Junto a la vieja colegiata», el 10 de enero de 1914. Aunque no llegó a publicar «En un cementerio castellano» antes de 1922, Unamuno fechó el poema en dos manuscritos de trabajo en febrero de 1913.

Un minucioso cotejo de los borradores conservados de dichos poemas nos muestra la vacilación del autor a la hora de plasmar sus composiciones, ora en verso, ora en prosa. De esta forma, observamos cómo don Miguel, a pesar de proyectar, en origen, todas estas composiciones en verso, coincidiendo con lo apuntado para los once poemas anteriores, altera el formato en las «copias en limpio», donde transcribe las composiciones a renglón seguido e, incluso, llega a publicar una primera versión en prensa, manteniendo esta misma forma tipográfica en el texto final. Este sería el caso de «Galicia», «El cristo yacente de Santa Clara», «¡Bienaventurados los pobres!»y «Las estradas de Albia» que fueron pensados en verso, siguiendo el esquema ya visto de la silva libre impar. En cuanto a «En un cementerio castellano», a pesar de no haber sido publicado antes de las «Visiones rítmicas», donde mantiene su forma en verso original, hemos localizado un manuscrito de trabajo, con signatura 61/2, que contiene una copia en limpio del poema, pero con el formato de prosa.

\section{Conclusiones}

Finalmente, del mencionado poemario en prosa no quedaría más que el andamiaje, disperso en decenas de manuscritos olvidados en el archivo de la Casa Museo. Sin embargo, una década más tarde Unamuno retomaría las notas del borrador de ese prólogo inédito e inconcluso para la redacción de la parte introductoria de sus «Visiones rítmicas», publicadas a modo de epílogo de Andanzas y visiones españolas. Ya en 1958, García Blanco (1958: 31) señaló la semejanza entre las reflexiones plasmadas en el autógrafo y las publicadas en el texto de 1922. De esa forma, el autor cierra el volumen con un «ramillete» de «poesías» que «brotaron» a raíz de los viajes referidos en él. Destaca que el poeta se refiera a este grupo de composiciones siempre con el nombre de «poesías» o «versos», a pesar de presentar algunos en la forma tipográfica de la prosa ${ }^{10}$. En efecto, la poesía no se reduce para Unamuno al verso y en

${ }^{10}$ Don Miguel justifica esta elección con las siguientes palabras: «Respecto a la forma externa o tipográfica de estos escritos he respetado en algunos la que al publicarlos por vez primera los di y es ponerlos como si fueran prosa, sin hacer un renglón aparte de cada verso. Lo que por un lado obliga al lector a estar más alerta en su lectura y no dejarse guiar del artificio tipográfico — que a las veces simula versos donde no los hay - y por otra lleva más papel. [...] A otras de estas poesías —o visiones en verso- les he conservado, en cambio, la tradicional manera de presentar los escritos medidos en cadencia acompasada» (Unamuno 1922: 258). 
varios de sus escritos aparece la asidua «alusión de que muchos [...] no son sino poemas abortados o versos sin separación tipográfica» (Imízcoz 1996: 212).

Por lo tanto, a la luz de los documentos autógrafos analizados, podemos concluir cómo, ante la indiferencia generalizada que supuso su primera obra poética, Unamuno concibió un segundo poemario en 1907 que sirviera de justificación para las innovaciones operadas en su poesía, especialmente, a nivel formal. Asimismo, su afán por experimentar con todos los géneros le conduce al hallazgo de una prosa «ritmoide» ${ }^{11}$ que le sirve como cauce vehicular para la expresión de su pensamiento, independientemente de la forma y del tipo de discurso adoptado. De este modo, y como él mismo llega a admitir, su incipiente faceta de autor teatral unida a la constante práctica de componer sonetos, opera en nuestro poeta un cambio sustancial, gracias al cual aceptará la tan anteriormente aborrecida rima generatrice. Y es en torno a 1912 y 1913 cuando comienza de una forma más insistente, no solo a teorizar sobre esta nueva forma de expresión protoplasmática que igualaría el verso a la prosa, sino que se resuelve a llevarla a la práctica con la composición de una serie de poemas en prosa.

Por otro lado, no hay que olvidar el magnífico trabajo de la profesora Lago Lapesa (1962: 7), quien, orientada por el magisterio de su predecesor García Blanco, realiza un minucioso estudio de uno de los cuentos que don Miguel compuso en torno a 1912 y lo dio a conocer, al igual que la mayoría de poemas en prosa, en Los Lunes de El Imparcial el 15 de julio de ese mismo año. En este ensayo se demuestra que «Cruce de caminos» es, sin lugar a dudas, una composición en verso, pero que su propio autor consideró como relato breve al insertarlo en la recopilación de cuentos El espejo de la muerte, publicado un año más tarde por la editorial Renacimiento.

Asimismo, conviene recordar la estrecha relación que existió entre el nacimiento y desarrollo del poema en prosa y del vesolibrismo ${ }^{12}$, y que junto al cuento poético y al fragmento, constituyen las nuevas modalidades literarias modernistas de clara raigambre romántica; todas estas, expresiones literarias (o más bien poéticas), que don Miguel experimentó, en particular, a partir de 1912. Creemos que este proyectado poemario en prosa pudo ser una primera tentativa del autor de dar respuesta a esa creciente «estética de la brevedad», presente en otros escritores de la época (Ródenas 2009: 68). Al no conservar testimo-

${ }^{11}$ Concepto este de la prosa «ritmoide» que algunos críticos, como Imícoz (1996: 245), identifican claramente con la expresión «poema en prosa», tal y como Unamuno lo expresó al final del borrador del prólogo presentado anteriormente.

12 Paraíso lo sitúa en 1886 con Rimbaud, Laforgue o Moréas, mientras que otros autores relacionan el origen del verso libre con la publicación en 1885 de Leaves of Grass, de Walt Whitman (León 1999: 56). Y no olvidemos que el poeta estadounidense supuso una auténtica revelación para Unamuno por su modo de concebir el ritmo en la poesía. 
nios directos del poeta, no podemos afirmar con rotundidad las causas que llevaron a Unamuno a la no publicación de este volumen de poesía. Pero no hay que olvidar que a partir de 1913, don Miguel se encuentra inmerso en la redacción del que será su tercer libro en verso, El Cristo de Velázquez. Y, por lo tanto, tal y como sucedió con tantos otros proyectos, puede que interrumpiera su composición, al derivar su práctica versificatoria, en ese momento, en un libro de corte diferente, pero en el que continuó desarrollando su teoría del endecasílabo como verso orgánico y libre.

En efecto, todos estos testimonios revelan que Unamuno, al menos, intentó crear una forma de expresión única, válida para cualquier tipo de discurso, ya sea este la expresión poética de un sentimiento suscitado por la visión de la naturaleza o una narración poética. Se trataría de esa forma protoplasmática de la lengua, anterior a cualquier diferenciación entre la prosa y el verso, pues todo, al fin y al cabo, es poesía. En el ensayo «Estilismo y estilo», fechado el 11 de mayo de 1924 e incluido en la obra conjunta de Alrededor del estilo, Unamuno insiste en diferenciar al diestro versificador del verdadero poeta ${ }^{13}$, pues este en sus poemas tiene que saber engarzar el pensamiento con el sentimiento, así como dar forma a su creación a través de su esencia, del ritmo; ritmo que para don Miguel residía en el número áureo impar, en especial, el endecasílabo, por ser este el más orgánico de todos al reflejar de una forma natural y armónica la espontaneidad de la lengua española.

Contrariamente a lo sostenido por algunos críticos, en España sí que habría calado, más de lo que se piensa, el mensaje simbolista de autores como Mallarmé o Whitman, que pretendían unificar la prosa y el verso a través del ritmo (Utrera 1999: 260 y 289), y no rinde justicia a nuestra generación modernista el considerar a Juan Ramón Jiménez como el único poeta interesado por el género del poema en prosa. Pues, como se evidencia del análisis de los manuscritos de trabajo presentados a lo largo del artículo, Unamuno ya puso en práctica esta voluntad de fundir los límites de la prosa y la poesía antes de la publicación de Platero y yo (1914) o Diario de un poeta recién casado (1916) (Gómez Trueba 1995: 15), obras consideradas como hitos dentro de la literatura española por asimilar «prosa y verso como manifestaciones poéticas equivalentes en cuanto a la musicalidad y el ritmo» (Utrera 1999: 265).

13 «Hay versificadores, y muy buenos según la preceptiva, y hay, en cambio, quien escribiendo en prosa, y de química o geometría analítica o un tratado del juego del ajedrez, es poeta. Pocos poemas son más poéticos, con más estilo, que la Ética de Spinoza, por caso.

El estilista es, pues, un literato —otras veces un sabio-, mientras que el hombre que escribe con estilo es un poeta, es un hombre que sabe y siente - siente apasionadamentelo que sabe y lo que siente. Y algunas veces el poeta hace versos. Si es que en el fondo no es verso, o por lo menos ritmo, lo que escribe, siendo su escribir un hacer, un crear» (Unamuno 1969: 893). 
Reiteramos la importancia de los documentos autógrafos hallados, que demostrarían cómo Unamuno ya en 1912 lleva a la práctica su reflexión teórica sobre la no distinción entre la prosa y el verso, llegando a borrar las fronteras entre un género (prosa narrativa) y otro (lírica). De esta forma, nuestro trabajo se inserta dentro de la línea crítica que ya apuntó la tendencia de Unamuno a evitar el «encasillamiento» de la poesía a un género concreto (Álvarez 2005: 211) y que tendría como origen la particular concepción que don Miguel tenía de la poesía, entendida esta «en su sentido etimológico de creación» (Álvarez 2005: 77).

\section{BIBLIOGRAFÍA CITADA}

Álvarez Castro, Luis (2005). La palabra y el ser en la teoría literaria de Unamuno. Salamanca: Universidad de Salamanca.

Antón Casaseca, Francisco (1907). «Sobre Poesías de Miguel de Unamuno», Ateneo. Segundo Año, III, pp. 485-488.

Ayuso, Paulino (2000). «Soledad y dialogismo en el Rosario de Sonetos Líricos de Unamuno», Cuadernos de la Cátedra Miguel de Unamuno. 35, pp. 53-76.

Biasi, Pierre-Marc de (2008). «¿Qué es un borrador? El caso Flaubert: ensayo de tipología funcional de los documentos de génesis», en Emilio Pastor Platero (ed.), Genética Textual. Madrid: Arco / Libros.

Blasco Pascual, Javier, María del Pilar Celma Valero y José Ramón González García (2003). Miguel de Unamuno, poeta. Valladolid: Universidad de Valladolid.

Blázquez González, Jesús Alfonso (2007). Miguel de Unamuno y Bernardo G. de Candamo: amistad y epistolario (1899-1936). Madrid: Ediciones 98.

Domínguez Caparrós, José (2010). El moderno endecasílabo dactílico, anapéstico o de gaita gallega. Sevilla: Padilla Libros Editores \& Libreros.

García Blanco, Manuel (1954). Don Miguel de Unamuno y sus poesías. Estudio y antología de textos poéticos no incluidos en sus libros. Salamanca: Universidad de Salamanca.

García Blanco, Manuel (1958). Cincuenta poesías inéditas. Madrid: Papeles de Son Armadans.

Gómez Trueba, M. ${ }^{a}$ Teresa (1995). Estampas líricas en la prosa de Juan Ramón Jiménez. Retrato, paisajes y recuerdos. Valladolid: Universidad de Valladolid.

González de Durana, Javier (1986). Cartas intimas. Epistolario entre Miguel de Unamuno y los hermanos Gutiérrez Abascal. Bilbao: Estudios Gráficos.

Imízcoz Beunza, Teresa (1996). La teoría poética de Miguel de Unamuno. Pamplona: Ediciones Universidad de Navarra.

Jiménez, Juan Ramón (1999). El modernismo: apuntes de curso (1953). Madrid: Visor.

Lacoue-Labarthe, Philippe y Jean-Luc Nancy (2012). El absoluto literario. Teoría de la literatura del romanticismo alemán. Argentina: Eterna Cadencia Editora.

Lago Lapesa, Pilar (1962). «Una narración rítmica de Miguel de Unamuno», Cuadernos de la Cátedra Miguel de Unamuno. 12, pp. 5-14.

La Rubia Prado, Francisco (1996). Alegorías de la voluntad: pensamiento orgánico, retórica y deconstrucción en la obra de Miguel de Unamuno. Madrid: Ediciones Libertarias/ Prodhufi. 
León Felipe, Benito (1999). El poema en prosa en España (1940-1990). Volumen I. Universidad de La Laguna (tesis).

Lorenzo Grandín, Pilar (1987-1989). «El soneto o el devenir de una nueva estética: de Santillana a Garcilaso», Estudios Románicos. V, pp. 785-796.

Machado, Manuel (1981). La guerra literaria, ed. Javier Blasco y M. ${ }^{a}$ Pilar Celma. Madrid: Narcea.

Paraíso, Isabel (1985). El verso libre hispánico. Madrid: Gredos.

Paraíso, Isabel (2000). La métrica española en su contexto románico. Madrid: Arco/Libros.

Ribbans, Geoffrey (1996). «Indigesto, mezquino, pedestre, confuso: a Hostil Contemporary Critique of Unamuno's Poesías (1907)», Revista Canadiense de Estudios Hispánicos. XXI, 1, pp. 203-216.

Rincón Córcoles, Antonio (2004). «Fibonacci y el número áureo», ACTA. 34, pp. 73-81.

Robles, Laureano (1991). Epistolario inédito 1 (1894-1914). Madrid: Espasa-Calpe.

Robles, Laureano (1996). Epistolario americano (1890-1936). Salamanca: Universidad de Salamanca.

Ródenas de Moya, Domingo (2009). «La microtextualidad en la vanguardia histórica», en Salvador Montesa (ed.), Narrativas de la posmodernidad. Del cuento al microrrelato. España: AEDILE, pp. 67-90.

Romero Luque, Manuel (1992). Las ideas poéticas de Manuel Machado. Sevilla: Diputación Provincial de Sevilla.

Tellechea Idígoras, Ignacio (2001). «Unamuno y Francisco Antón Casaseca. Epistolario», Cuadernos de la Cátedra Miguel de Unamuno, 36, pp. 145-276.

Unamuno, Miguel de (1914). Niebla (nivola). Madrid / Buenos Aires: Renacimiento.

Unamuno, Miguel de (1922). Andanzas y visiones españolas. Madrid: Renacimiento.

Unamuno, Miguel de (1958). Obras Completas. VIII. Letras de América y otras lecturas. Madrid: Afrodisio Aguado.

Unamuno, Miguel de (1966a). Obras Completas. Tomo V. Teatro completo y monodiálogos. Madrid: Escelicer.

Unamuno, Miguel de (1966b). Obras Completas. Tomo VIII. Autobiografía y recuerdos personales. Madrid: Escelicer.

Unamuno, Miguel de (1969). Obras Completas. Ensayos. Tomo VII. Madrid: Escelicer.

Utrera Torremocha, María Victoria (1999). Teoría del poema en prosa. Sevilla: Universidad de Sevilla.

Fecha de recepción: 2 de julio de 2015.

Fecha de aceptación: 30 de septiembre de 2016. 